\title{
Diet of Bryconops alburnoides and B. caudomaculatus (Osteichthyes: Characiformes) in the region affected by Balbina Hydroelectric Dam (Amazon drainage, Brazil)
}

\author{
Cylene C. da Silva, Efrem J. G. Ferreira and Cláudia P. de Deus
}

The study of fish diet and its interaction with the environment provides important data on ecology and behavior, as fish face varying environmental and food availability conditions. The aim of the present study was to determine the diet of Bryconops caudomaculatus and Bryconops alburnoides, as well as to assess its seasonal variation, within the area influenced by Balbina Hydroelectric Dam (BHD), in the Uatumã River (Amazon Basin, Brazil). Collections were carried out every two months from April 2005 to February 2007, using gill nets with mesh sizes ranging from 12 to $60 \mathrm{~mm}$ between opposite knots. Two methods were used for determining diet: frequency of occurrence and relative volume, which were used to calculate the alimentary index (IAi). Diet similarity between species was analyzed by applying the Morisita index. Bryconops alburnoides ingested 12 items and B. caudomaculatus 10 , with a 59\% similarity between ingested items. Terrestrial insects for B. alburnoides and immature insects for B. caudomaculatus were the main items in their diets, and therefore, they were considered insectivorous. The seasonal composition of the diet of B. alburnoides was influenced by environmental factors, and in spite of the dominance of immature insects, it had a significant number of terrestrial insects during the heavy rainfall periods.

O estudo da dieta de peixes e sua interação com o ambiente fornecem importantes informações ecológicas e comportamentais das espécies frente às variações nas condições ambientais e de disponibilidade de alimento. Este estudo teve por objetivo determinar a alimentação de Bryconops caudomaculatus e Bryconops alburnoides e avaliar suas diferenças sazonais na área de influência da UHE Balbina, rio Uatumã, Amazonas. As coletas foram realizadas bimestralmente de abril/2005 a fevereiro/2007, utilizando-se redes de espera com malhas variando de 12 a $60 \mathrm{~mm}$ entre nós opostos. Foram utilizados dois métodos na determinação da dieta: freqüência de ocorrência e volume relativo, sendo ambos combinados no Índice Alimentar (IAi). A similaridade da dieta entre as espécies foi analisada aplicando-se o índice de Morisita. Ambas as espécies apresentaram a dieta diversificada. Bryconops alburnoides ingeriu 12 itens e B. caudomaculatus 10, com uma similaridade de 59\% entre os itens ingeridos. Os insetos terrestres para $B$. alburnoides e os imaturos para $B$. caudomaculatus foram os itens que mais se destacaram nas dietas, portanto foram consideradas insetívoras. Fatores ambientais influenciaram na sazonalidade da composição da dieta de B. alburnoides, apesar dos insetos imaturos serem mais preponderantes na dieta da espécie, houve uma ingestão significativa de insetos terrestres nos períodos de maior pluviosidade.

Key words: Feeding ecology, Reservoir, Amazon, Environmental impact.

\section{Introduction}

The increasing demand for electric power generation since the 1960s has turned hydroelectric dams into a common component of the Brazilian landscape (Agostinho et al., 1992; Benedito-Cecilio \& Agostinho, 2000). In the Amazonian region this demand has increased mainly on account of its high potential for producing low cost hydroelectric power since it is the world's largest basin, draining an area of nearly $7.1 \times 10^{6}$ $\mathrm{km}^{2}$ (Goulding et al., 2003). The consequence of such enter- prise is the marked modification of physical, chemical and biological attributes of the fluvial system, causing alterations in the composition and abundance of its original fish fauna (Agostinho et al., 1992).

The construction of a dam changes the original river from a lotic into a lentic environment, and very often from a fish community dominated by migratory species into one dominated by sedentary fish (Welcomme, 1979). The species remaining in these new environments will be those showing better adaptive ability to the conditions brought about by the

Instituto Nacional de Pesquisas da Amazônia - INPA, Coordenação de Pesquisas em Biologia Aquática - CPBA, Cx.Postal 478, 69011-970 Manaus, AM, Brazil. cylenecamara@yahoo.com.br; efrem@inpa.gov.br; claudias@inpa.gov.br 
dam construction. Flexibility in feeding and reproduction are attributes common to many of the most abundant fish species found in reservoirs (Ferreira, 1984; Agostinho et al., 1999).

The interaction of fish with their surrounding environment is reflected in the diet and provides major ecological and behavioral information, thus adding to the better understanding of the mechanisms which enable several species to coexist and exploit their resources from one and the same system (Goulding, 1980).

Bryconops alburnoides Kner, 1858 and B. caudomaculatus (Günther, 1864) are the most abundant species in the Balbina Hydroelectric Dam (BHD) reservoir (E. J. G. Ferreira, unpublished data), demonstrating the importance of these species in this environment.

To understand how B. alburnoides and B. caudomaculatus survived and adapted to the new environment created by the damming of the river, one of the initial steps is to know their diets. Thus, two questions can be established: (i) what are the predominant food resources maintaining the species in this environment? (ii) Is there seasonal variation in the diet of these species? This work sought to assess the feeding spectrum and main resources making up the diet of B. alburnoides and B. caudomaculatus within the area influenced by BHD.

\section{Material and Methods}

Study Area. Balbina Hydroelectric Dam is located on the Uatumã River, a tributary of the left bank of the Amazon River, between the Negro and Trombetas rivers. The Uatumã River drains a basin of nearly 70,600 $\mathrm{km}^{2}$ and two distinct morphostructural zones: the Guyana Shield in its upper and midcourses and the Amazonian sedimentary basin in the lower course. It has been classified as a black-water river (Santos \& Jegu, 1996). The Uatumã basin is dominated by a dense tropical forest and countless streams. Balbina Hydroelectric Dam began to operate in 1989. Its reservoir covers an area of 2,360 $\mathrm{km}^{2}$ (Fearnside, 1990), and it was, on account of its huge flooded area, the world's fifth largest reservoir coming under operation at that time (Avakyan \& Lakovleva, 1998). The Uatumã Biological Reserve (REBIO do Uatumã), created in 1990 for the purpose of protecting representative samples of the ecosystems encompassing the basins of the Uatumã and Jatapu rivers, is on the left bank of the Balbina dam.

Sampling. Fish were collected at four sampling stations. Two in the lotic river section (station 1, Cachoeira Morena, $2^{\circ} 7^{\prime} 23.6^{\prime \prime}$ S and 59 19'49.3" W; station 2, downstream from the dam, $1^{\circ} 55^{\prime} 11.8^{\prime \prime} \mathrm{S}$ and $59^{\circ} 28^{\prime} 19.0^{\prime \prime} \mathrm{W}$ ); and two in the reservoir (station 3, upstream from the dam, $1^{\circ} 54^{\prime} 23^{\prime \prime} S$ and $59^{\circ} 27^{\prime} 39.4^{\prime \prime}$ W; station 4, Base Waba, 1'31'19.5" S and 5949'18.0" W, on the reservoir margin opposite to the REBIO).

Sampling was carried out every two months from April 2005 to February 2007 using gillnets with mesh sizes ranging from 12 to $60 \mathrm{~mm}$ between opposite knots. The nets remained set for $8 \mathrm{~h}$, from 04:00 to 08:00 and from 16:00 to 20:00 h (periods when most fish are captured). This procedure was used to avoid the frequent attacks of dolphins and alligators on the netted fish, which destroyed the fishing nets.

Following their removal from gillnets, the fish were kept on ice and taken to the laboratory where they were identified, measured (standard length), weighed, and dissected for the removal of their stomachs. The stomachs were labelled and preserved in 70\% alcohol. Voucher specimens were deposited at the Instituto National de Pesquisas da Amazônia fish collection (B. alburnoides, INPA 25511, and B. caudomaculatus, INPA 25506).

Diet Analysis. Food items were grouped into twelve categories: adult aquatic insects (Coleoptera and Hemiptera); adult terrestrial insects (Isoptera, Hymenoptera, Orthoptera, Hemiptera and Diptera); immature aquatic insects (Ephemeroptera and Diptera larvae, pupae and nymphs); non-identified insect fragments; fish (scales, muscle, otoliths, fin-rays and whole fish); plants (plant debris, seeds, flowers, fruits and aquatic macrophytes); detritus (amorphous organic matter); microcrustaceans (copepods, cladocerans, ostracods and conchostracans); macroinvertebrates (arachnids and nematodes); bird fragments (Psittacidae feather and bone fragments); phytoplankton (Pleuroterium sp., Desmidium sp., Closterium sp., Triploceras sp. and Micrasterias sp.); and non-identified items.

Diet analysis was carried out in two ways: frequency of occurrence (Hyslop, 1980) and, for assessing the volume of each food item, the points method proposed by Hynes (1950, modified by Soares 1979), where a visual estimate of the relative volume is made of each stomach content item. Since we considered each stomach as having $100 \%$ total volume, these values were multiplied by the stomach fullness to correct the relative value. The stomach fullness (SF) was estimated through a visual volume assessment, for one of the following intervals: $0 \%, 10 \%, 25 \%, 50 \%, 75 \%$, and $100 \%$, according to Goulding et al. (1988). Both methods were combined in the alimentary index (IAi) (Kawakami \& Vazzoler, 1980), with values ranging from 0 to $1(1 \geq \mathrm{IAi} \geq 0)$, described by the equation below:

$$
I A i=F i x V i / \sum_{i=1}^{n}(F i x V i)
$$

where:

$\mathrm{i}=$ food item ranging from 1 to $\mathrm{n}$

$\mathrm{Fi}$ = frequency of occurrence $(\%)$ of item $\mathrm{i}$

$\mathrm{Vi}=$ volume $(\%)$ of item $\mathrm{i}$

IAi values were later converted into percentages and designated IAi\%. This index was used for determining the species trophic category.

To determine if there were any differences in the diets of B. caudomaculatus in the river and reservoir environments, we used the indices of Morisita's similarity (quantitative com- 
parisons) (Krebs, 1999) and Jaccard (presence-absence comparisons) (Magurran, 1988). Morisita’s similarity index was also applied in the comparison between B. alburnoides and B. caudomaculatus. For the Morisita index, values over 75\% indicate high similarity (Matthews, 1986), but for the Jaccard index, estimated values under $60 \%$ indicate a substantial difference in the availability of items (Rahel, 1990). The feeding similarity between the species was determined by cluster analysis (Ludwig \& Reynolds, 1988), using the UPGMA method and Morisita distances, and the software PAST v. 1.66 (Hammer et al., 2001).

Rainfall data were furnished by the Manaus Energia operating sector at Balbina Hydroelectric Plant.

\section{Results}

A total of 854 specimens of B. alburnoides ( 80 - $140 \mathrm{~mm}$ ) and 118 specimens of $B$. caudomaculatus $(57-120 \mathrm{~mm}$ ) were captured. Bryconops alburnoides was collected in the reservoir only and 532 had food in their stomachs. Forty-two individuals of $B$. caudomaculatus captured in the river and 40 individuals captured in the reservoir were analyzed (Table 1 ).

Both species were found to use a broad variety of food items; $B$. alburnoides ingested twelve different items and $B$. caudomaculatus, ten.

Despite the diversity of items consumed, terrestrial insects were most frequently found in the stomach contents of B. caudomaculatus, while immature aquatic stages were found in the stomach contents of B. alburnoides. However, the latter also showed a significant ingestion of terrestrial insects. Thereby, both species were trophically classified as insectivorous (Table 1).

The dendrogram of the cluster analysis (Morisita distance) based on food items defined two groups. The first was represented by B. alburnoides and the second by B. caudomaculatus from both river and reservoir. These two groups are segregated due to $B$. alburnoides preferential ingestion of terrestrial insects and to B. caudomaculatus preferential ingestion of immature insects (Fig. 1).

The diet of B. caudomaculatus showed no seasonal variation. Terrestrial insects were the main food item found throughout the study period (Fig. 2a). The similarity indices were high (Morisita $=95 \%$; Jaccard = 90\%). Bryconops alburnoides showed seasonal variation in the ingestion of immature and terrestrial insects (Morisita = 59\%; Jaccard = 37\%). Immature insect stages were predominant in almost all months, but there were high terrestrial insect abundances in June 2005 and February 2006 which were directly related to the heavier rainfall at that time (Fig. 2b).

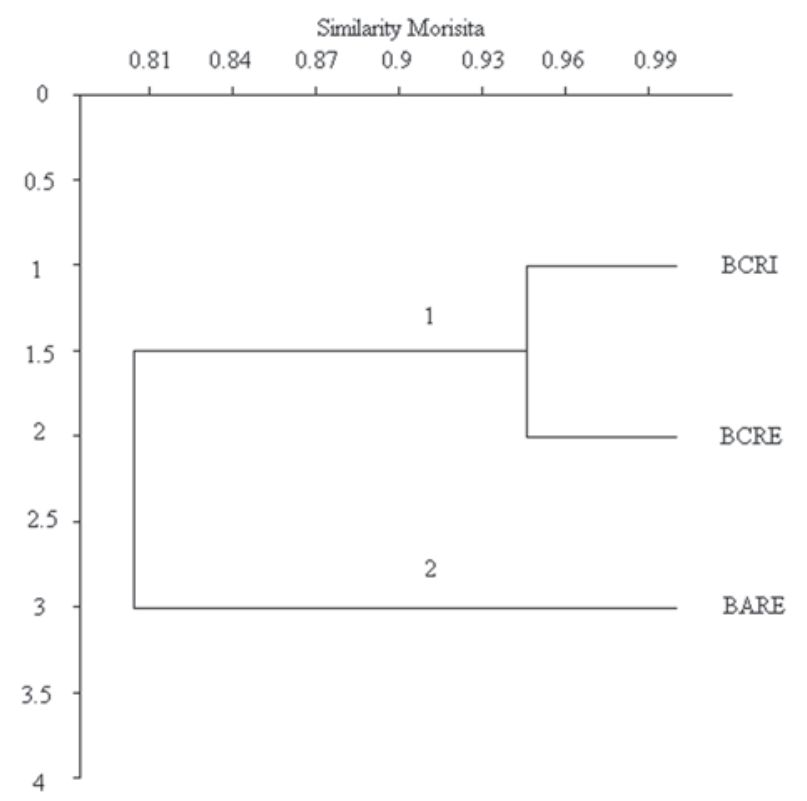

Fig. 1. Diet similarity based on food items found in stomachs of Bryconops (BC = B. caudomaculatus, $\mathrm{BA}=$ B. alburnoides; $\mathrm{RE}=$ reservoir; $\mathrm{RI}=$ river; 1 = ingestion predominantly composed of terrestrial insects; 2 = ingestion predominantly composed of immature insects).

Table 1. Alimentary index (IAi\%) based on stomach contents of Bryconops caudomaculatus and B. alburnoides in the region affected by the Balbina Reservoir, Uatumã River, Amazonas State, Brazil.

\begin{tabular}{lccc}
\hline \multicolumn{1}{c}{ Items } & $\begin{array}{c}\text { B. caudomaculatus } \\
\text { Reservoir }\end{array}$ & $\begin{array}{c}\text { B. caudomaculatus } \\
\text { River }\end{array}$ & $\begin{array}{c}\text { B. alburnoides } \\
\text { Reservoir }\end{array}$ \\
\hline Adult aquatic insects & 0.258 & 0.948 & 0.757 \\
Adult terrestrial insects & 76.728 & 95.602 & 26.254 \\
Immature aquatic insects & 21.351 & 2.898 & 69.206 \\
Fragments of unidentified insects & 0.720 & 0.220 & 1.065 \\
Fish & 0.720 & 0.119 & 0.091 \\
Plants & 0.097 & 0.107 & 0.057 \\
Detritus & 0.024 & 0.045 & 0.063 \\
Microcrustaceans & 0.558 & 0.001 & 2.501 \\
Macroinvertebrates & 0.024 & & 0.003 \\
Bird fragments & & 0.002 \\
Phytoplankton & & 0.060 & $<0.001$ \\
Unidentified & 0.120 & $42(13)$ & $<0.001$ \\
\hline Number of full stomachs (empty stomachs) & $40(23)$ & $532(322)$ \\
Standard length, min - max (mean) & $72-120(97)$ & & $80-140(104)$ \\
\hline
\end{tabular}



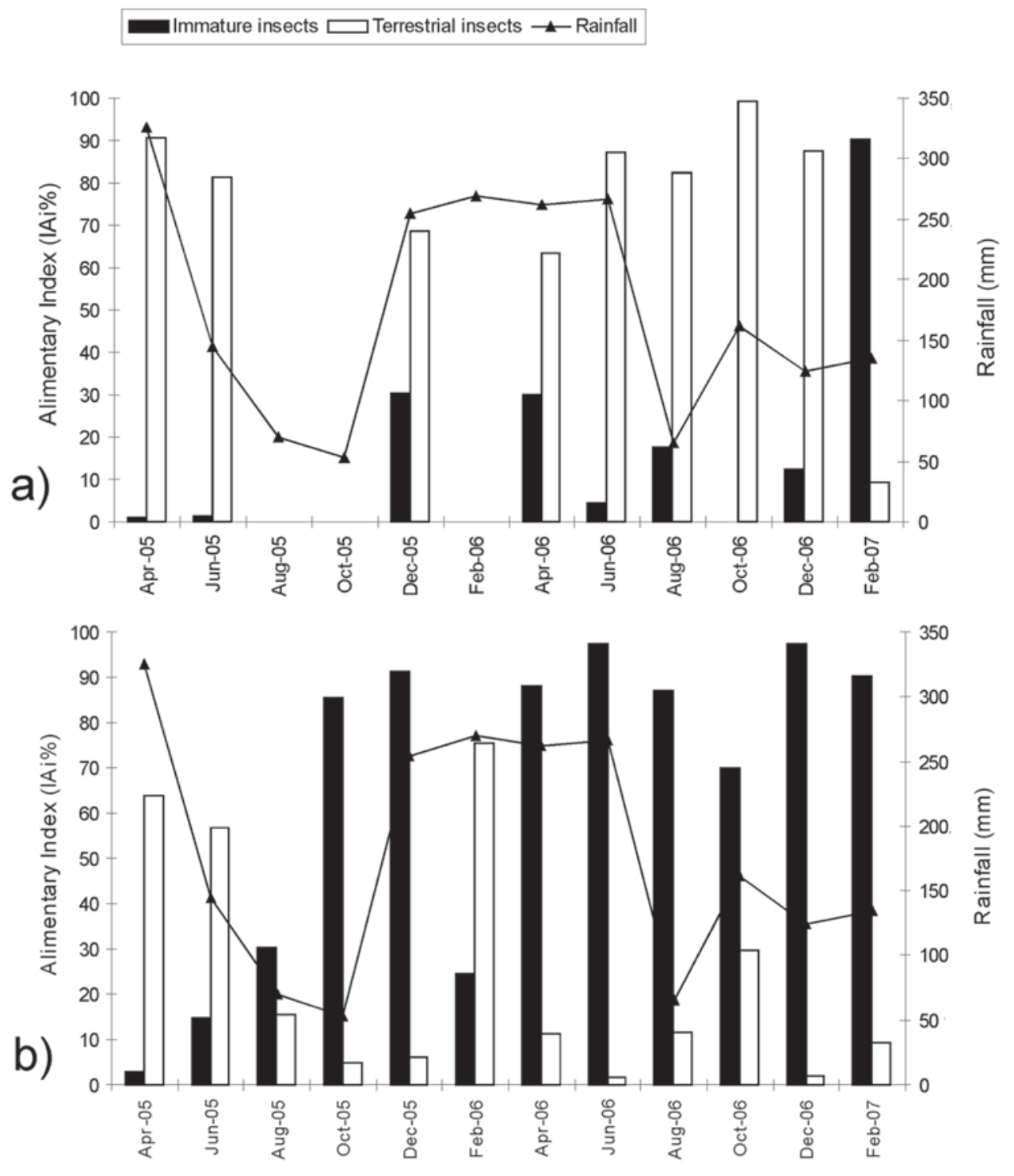

Fig. 2. Seasonal variation in role of terrestrial and immature insects in diet of B. caudomaculatus (a) and B. alburnoides (b) in the region affected by the Balbina Reservoir, Uatumã River, Brazil.

\section{Discussion}

The analyses of the diet of the Balbina fish community showed that, despite the great diversity of items consumed by the fish, which pointed to a flexible and opportunistic feeding, the species tended to have preferential items in their diet. Bryconops alburnoides had a preference for terrestrial insects and B. caudomaculatus for immature insects, and thus, the two species were classified as insectivores, which agrees with other studies of this genus.

The diet of B. giacopinii in Amazonian floodplain lakes was considered to be allochthonous invertivorous, where feeding was mainly on insects and spiders (Luiz Claro Jr., pess. com.). Abelha et al. (2001) also classified the species as invertivorous, having terrestrial insects as its main food. Mérona et al. (2001), in analyzing the diet of B. alburnoides before and after the closure of the Tucurui dam, found that the species fed mainly on terrestrial invertebrates. According to Goulding (1980), the dynamics between food availability and feeding spectrum of tropical fish is often influenced by the flood pulse. In dammed environments, as in the case of Balbina, the seasonal changes are little evident, and thereby, fish tend to be more specialist in these more stable environments, since the food resources they use are most likely to be available all year long (Lowe-McConnell, 1999).

Goulding et al. (1988) mention that insects are important in the diets of fish species in the Negro River, and Silva (2003) observed that immature forms of aquatic insects are important in the diet of stream fishes. In the Curuá-Una Reservoir (Curuá-Una River, Pará State), the main insects found among the stomach contents of fish were Ephemeroptera and Chaoboridae larvae. Ephemeroptera larvae, which live in submerged tree trunks that were very abundant in the reservoir, 
were the main food item of many fish species at this site (Ferreira, 1984). According to Winemiller (1990) and ZavalaCamin (1996), insects are more available during the high water period due to the flooding of marginal vegetation, and the action of winds and rain (Esteves \& Aranha, 1999), as seems to be the case at Balbina. Terrestrial insects, for example, falling from marginal trees down to the water, are important food resources in tropical rivers (Lowe-McConnell, 1999). They are an essential food for fishes, especially in rivers of low productivity (Lowe-McConnell, 1999, Goulding et al., 1988) such as black-water rivers, including the Uatumã River.

There was a direct relationship between rainfall and the presence of terrestrial insects in the diet of B. alburnoides. This relationship is probably due to the increased intensity of the wind in the rainy periods, favoring the entry of this item into the aquatic system. Bryconops alburnoides appears to have taken advantage of a resource that became abundant at this period. The action of wind and rain is reported by authors such as Mason \& MacDonald (1983) for a stream in England; these authors ascertained that the input of terrestrial invertebrates was bimodal, the two peaks being associated with extreme climatic conditions such as storms and strong winds. Henry et al. (1994) also noted the importance of winds on the entrance of invertebrates in the aquatic system, and Uieda \& Kikuchi (1995) reported the fall of a larger number of terrestrial invertebrates into the watercourse during the rainy season. Terrestrial invertebrates were abundant in the stomachs of B. caudomaculatus throughout the study period, both in river and reservoir environments. This food item appears to be the main source of energy supporting the B. caudomaculatus population at the site studied.

Rosseval Leite (pers. comm.) mentions the importance of terrestrial insects in the aquatic system at the time prior to the damming of the Uatumã River. According to his findings, the insects of the family Formicidae stood out as the mostly frequently consumed by the Uatumã River fishes. Eighteen years after the damming of the Uatumã River, insects continue being a highly important food resource in the community, especially the terrestrial forms and the immature stages, demonstrating their high availability in the environment (C. C. Silva, unpublished data). Food supply is, therefore, one of the determining factors in the establishment and success of fish in dammed rivers (Agostinho \& Gomes, 1997).

Insects were the main source of food for the two species of Bryconops, but the feeding strategies of the two species were different. Bryconops alburnoides showed greater flexibility in the strategies as the availability of the items varied. The occurrence of these species together in the same environment (reservoir) can indicate that food, although an important factor for the establishment of the community (Gerking, 1994), is not a limiting factor for the species. The two species can forage in different levels of the water column (B. caudomaculatus more at the surface, feeding on terrestrial insects, and B. alburnoides on the immature insects attached to the benthos or on adult insects of allochthonous origin). This fact reveals that B. alburnoides can be classified into two different guilds, given the seasonal differences in its diet. Species can change their functional role within a community throughout their life cycle or during seasons of the year depending on the circumstances of the environment. For this reason, seasonal observations are fundamental in the study of fish diet, in order to avoid incorrect guild allocation, particularly in environments that suffered and still suffer drastic changes in physical and physical-chemical conditions, as in the case of hydroelectric dam reservoirs.

\section{Acknowledgments}

We are indebted to Manaus Energia S.A. for logistical support at Vila de Balbina. We also thank Mr. Jorge Antunes and Dr. Barbara Robertson for their help in drafting the original English version and Dr. A. Leyva for final English editing of the manuscript. CNPq awarded a grant to the first author. IBAMA granted Environmental licenses 007/2005 and 007/ 2006. This study was financially supported by the Research Support Foundation of Amazonas State (FAPEAM) (PIPT 815/ 04) and CNPq (Proc. No. 473978/2004-0 - Universal 2004).

\section{Literature Cited}

Abelha, M. C. F., A. A. Agostinho \& E. Goulart. 2001. Plasticidade trófica em peixes de água doce. Acta Scientiarium, 23(2): 425434.

Agostinho, A. A. \& L. C. Gomes. 1997. Manejo e monitoramento de recursos pesqueiros: perspectivas para o reservatório de Segredo. Pp. 319-364. In: Agostinho, A. A. \& L. C. Gomes (Eds). Reservatório de Segredo: bases ecológicas para o manejo. Maringá, EDUEM, 387p.

Agostinho, A. A., H. F. J. Júlio Júnior \& J. R. Borghetti. 1992. Considerações sobre os impactos dos represamentos na ictiofauna e medidas para sua atenuação, um estudo de caso: reservatório de Itaipu. Revista Unimar, 14: 89-107.

Agostinho, A. A., L. E. Miranda, L. M. Bini., L. C. Gomes., S. M. Thomaz \& H. I. Suzuki. 1999. Patterns of colonization in Neotropical reservoirs, and prognoses on aging. Pp. 227-266. In: Tundisi, J. G. \& M. Straskraba. (Eds.). Theoretical reservoir ecology and its applications. São Carlos, International Institute of Ecology, 585p.

Avakyan, A. B. \& V. B. Lakovleva. 1998. Status of global reservoirs: the position in the late twentieth century. Lakes \& Reservoirs: Research and Management, 3(1): 45-52.

Benedito-Cecilio, E. \& A. A. Agostinho. 2000. Distribution, abundance and use of different environments by dominant ichthyofauna in the influence area of the Itaipu Reservoir. Acta Scientiarum, 22(2): 429-437.

Esteves, K. E. \& J. M. R. Aranha. 1999. Ecologia trófica de peixes de riachos. Pp. 157-182. In: Caramaschi, E. P., R. Mazzoni., C. R. S. F. Bizerril \& P. R. Peres-Neto (Eds). Ecologia de peixes de riachos: estado atual e perspectivas. Série Oecologia Brasiliensis, vol. 6, PPGE-UFRJ, Rio de Janeiro, 260p.

Fearnside, P. 1990. A hidrelétrica de Balbina: O faraonismo irreversível versus ambiente na Amazônia. São Paulo. IAMÁ, 46p. 
Ferreira, E. J. G. 1984. A ictiofauna da represa hidrelétrica de CuruáUna. Santarém, Pará. II: Alimentação e hábitos alimentares das principais espécies. Amazoniana, 9(1): 1-16.

Gerking, S. D. 1994. Feeding Ecology of Fish. San Diego, Academic Press, 416p.

Goulding, M. 1980. The fishes and the forest. Exploration in Amazonian Natural History. Berkeley, University of California Press, 280p.

Goulding, M., R. Barthem \& E. J. G. Ferreira. 2003. The Smithsonian: Atlas of the Amazon. Washington, Smithsonian Books, 253p.

Goulding, M., M. L. Carvalho \& E. J. G. Ferreira. 1988. Rio Negro: rich life in poor water. Hague, The Netherlands, SPB Academic Publishing, 200p.

Hammer, O., D. A. T. Harper \& P. D. Ryan. 2001. PAST: Paleontological Statistics Software Package for Education and Data Analysis. Palaeontologia Electronica 4(1): 9p.

Henry, R., V. S. Uieda., A. A. Afonso \& R. M. Kikuchi. 1994. Input of allochthonous matter and structure of fauna in Brazilian headstream. Verh International. Verein Limnology, 25: 18661870.

Hynes, H. B. N. 1950. The food of freshwater sticklebacks (Gasterosteus aculeatus and Pygosteus pungitius) with a review of methods used in the studies of the food of fishes. Journal of Animal Ecology, 19: 35-58.

Hyslop, E. J. 1980. Stomach contents analysis - a review of methods and their application. Journal of Fish Biology, 17: 411-429.

Krebs, C. J. 1999. Ecological methodology. New York, Addison Wesley Longman, 620p.

Lowe-McConnell, R. H. 1999. Estudos Ecológicos de comunidades de peixes tropicais. São Paulo, EDUSP, 534p.

Ludwig, J. A. \& J. F. Reynolds. 1988. Statistical ecology. New York, John Wiley \& Sons, 337p.

Magurran, A. E. 1988. Ecological diversity and its measurement. London, Chapman \& Hall, 178p.
Mason, C. F. \& S. M. Macdonald. 1983. The input of terrestrial invertebrates from tree canopies to a stream. Freshwater Biology, 12: 305-311.

Matthews, W. J. 1986. Fish faunal structure in an Ozark stream: stability, persistence and a catastrophic flood. Copeia, 1986(2):388-397.

Mérona, B., G. M. Santos \& R. G. Almeida. 2001. Short term effects of Tucuruí Dam (Amazonia, Brazil) on the trophic organization od fish communities. Environmental Biology of Fishes, 60: 375392.

Rahel, F. J. 1990. The hierarchical nature of community persistence: a problem of scale. American Naturalist, 136:328-344.

Santos, G. M. \& M. Jegu. 1996. Inventário taxonômico dos anostomídeos (Pisces, Anostomidae) da bacia do rio UatumãAM, Brasil, com descrição de duas espécies novas. Acta Amazonica, 26(3): 151-184.

Soares, M. G. M. 1979. Aspectos ecológicos (alimentação e reprodução) dos peixes do igarapé do Porto, Aripuanã, MT. Acta Amazonica, 9: 325-352.

Silva, C. P. D. 2003. Alimentação e distribuição espacial de algumas espécies de peixes do igarapé do Candirú, Amazonas, Brasil. Acta Amazonica, 23(2-3): 271-285.

Uieda, V. S. \& R. M. Kikuchi. 1995. Entrada de material alóctone (detritos vegetais e invertebrados terrestres) num pequeno curso de água corrente na Costa de Botucatu, São Paulo. Acta Limnologica Brasiliensia, 7: 105-114.

Welcomme, R. L. 1979. Fisheries Ecology of Floodplain Rivers. London, Longman, 317p.

Winemiller, K. O. 1990. Spatial and temporal variation in tropical fish trophic networks. Ecological Monographs, 60: 331-367.

Zavala-Camin, L. A. 1996. Introdução ao estudo sobre alimentação natural em peixes. Maringá, EDUEM, 129p.

Accepted May 2008 Published June 28, 2008 